\title{
Protean and boundaryless career attitudes: relationships with subjective and objective career success
}

\author{
Judith Volmer · Daniel Spurk
}

Received: 27 January 2010 / Accepted: 14 July 2010 / Published online: 21 August 2010

(C) Institut für Arbeitsmarkt- und Berufsforschung 2010

\begin{abstract}
The protean and boundaryless career attitudes have gained special attention during the past years. A protean career attitude implies that a person strives towards a developmental progression and self-fulfillment; a boundaryless career attitude is characterized by a high physical and/or psychological mobility. The aim of the present paper is twofold: First, we want to empirically investigate the relationship between protean and boundaryless career attitudes and subjective (i.e., career satisfaction and success in comparison with colleagues) and objective (i.e., promotions and salary) career success. Second, we want to integrate research on protean and boundaryless career attitudes with research on predictors of career success. We analyze the career attitudes-career success relationship with a sample of 116 professionals. Our findings suggest that components of the protean career attitude are rather more related with subjective career success and that components of the boundaryless career attitude are more related with objective career success. Conclusions regarding the relevance of career attitudes for career success are drawn.
\end{abstract}

Keywords Protean career attitudes $\cdot$ Boundaryless career attitudes - Subjective and Objective career success . Changing work environments

J. Volmer $(\bowtie) \cdot D$. Spurk

University of Erlangen-Nuremberg, Social Psychology Group,

Bismarckstr. 6, 91054 Erlangen, Germany

e-mail: judith.volmer@sozpsy.phil.uni-erlangen.de

Tel.: +49-9131-8522959

Fax: +49-9131-8524731
„Proteische“ und ,grenzüberschreitende“" Karriereeinstellungen: Zusammenhänge mit subjektivem und objektivem Berufserfolg

Zusammenfassung Die proteische und entgrenzte Laufbahneinstellung haben seit einigen Jahren besondere Beachtung gefunden. Eine proteische Laufbahneinstellung beinhaltet, dass eine Person nach einer fortschreitenden Entwicklung und Selbstverwirklichung strebt; eine entgrenzte Laufbahneinstellung ist durch eine hohe physische und/oder psychische Mobilität gekennzeichnet. Dieser Beitrag verfolgt zwei Zielsetzungen: Erstens möchten wir den Zusammenhang zwischen proteischen und entgrenzten Laufbahneinstellungen mit subjektivem (d.h. Karrierezufriedenheit und Erfolg im Vergleich mit Kollegen) sowie objektivem (d. h. Beförderung und Gehalt) Berufserfolg untersuchen. Zweitens möchten wir Forschung zu proteischen und entgrenzten Laufbahneinstellungen mit Forschung zu Prädiktoren von Berufserfolg verknüpfen. Wir analysieren den Zusammenhang zwischen Laufbahneinstellung und Berufserfolg anhand einer Stichprobe von 116 Berufstätigen. Unsere Ergebnisse zeigen, dass Komponenten der proteischen Laufbahneinstellung eher mit subjektivem Erfolg und Komponenten der entgrenzten Laufbahneinstellung eher mit objektivem Erfolg zusammen hängen. Folgerungen bezüglich der Relevanz von Laufbahneinstellungen für den Berufserfolg werden abgeleitet.

Schlüsselwörter Proteische Laufbahneinstellungen . Entgrenzte Laufbahneinstellungen - Subjektiver und Objektiver Berufserfolg · Sich verändernde Arbeitswelten 


\section{Introduction}

Work is central for people's self-concepts and career success is important for individuals as well as for organizations (Hall 2002; Inkson 2006; Super 1957). Substantial changes in today's work environment such as rapid technological advancements, flattened hierarchies, and decreased job stability due to financial meltdowns have diminished individuals' opportunities to pursue a career within one single organization during their lifetime with prescheduled linear upward moves over time. A perspective on careers considering these developments as introduced, for instance, by Hall (1976) or Arthur and Rousseau (1996), is characterized by a shift of responsibilities for career progress from organizations to employees (e.g., Arthur and Rousseau 1996; Briscoe et al. 2006) and by an emphasis on the individual's freedom and growth as a core value (cf. Hall 1976, 2002, 2004). The message from this recently emerged perspective is clear: To be employable, people have to be flexible and adaptive.

We are concerned here with two key concepts within this career perspective: the protean career attitude (Hall 1976, 2004) and the boundaryless career attitude (Arthur 1994; Arthur and Rousseau 1996). A protean career attitude has been characterized as involving a broader perspective, a developmental progression, and viewing a career as a calling and a way to self-fulfillment (Hall 2002). A person with a boundaryless career attitude is characterized by high mobility and prefers to navigate physically and/or psychologically across many organizations (Sullivan and Arthur 2006). Both protean and boundaryless career attitudes have two components. The protean career attitude consists of a values-driven attitude and self-directed career management, the boundaryless career attitude is composed of an organizational mobility preference and a boundaryless mindset.

Previous studies have predominantly focused on methodological aspects such as the exploration of different types of career orientations (e.g. Briscoe and Hall 2006). Only some parts of the career attitude constructs have been used so far to predict career success (e.g., De Vos and Soens 2008; Gasteiger 2007). However, as the constructs have been developed as being independent but related, it makes sense to include both career attitudes into one analysis (e.g., Sullivan and Baruch 2009) to obtain a more comprehensive picture of the similarities and differences of protean and boundaryless career attitudes and their relationships with career success. Furthermore, previous research has focused mainly on subjective career success. Yet, considerations from career mobility research (e.g., Feldman and Ng 2007) suggest that career attitudes might also be associated with objective success.

The aim of the current study is twofold: first, we aim to empirically investigate the relationship between protean and boundaryless career attitudes and both subjective and objective career success. Second, we want to theoretically integrate assumptions and findings from research on protean and boundaryless career attitudes (Briscoe et al. 2006) with research on predictors of career success (e.g., $\mathrm{Ng}$ et al. 2005).

\section{Career success}

Career success defined as "positive psychological or workrelated outcomes or achievements one has accumulated as a result of one's work experiences" (Judge et al. 1995, p. 486) implies both subjective success and objective success. Subjective success is an individual's positive evaluation of his/her career. Indicators of subjective career success are, for example, career satisfaction and job satisfaction. Indicators of objective success are, for example, salary (e.g., Judge et al. 1995) and promotions (e.g., Boudreau et al. 2001). Meta-analytical research reveals that correlations between subjective and objective success are not higher than 0.30 (cf. Dette et al. 2004; $\mathrm{Ng}$ et al. 2005; cf. also Abele et al. (2010, this issue) for an overview). Therefore, it is important to consider both subjective and objective career success. In our study, we used two measures of subjective career success, namely career satisfaction (cf. Greenhaus et al. 1990) and evaluations of success compared with colleagues (cf. Heslin 2005). Similarly, we used two measures of objective career success, salary and promotions.

\section{Protean and boundaryless career attitudes}

In the following, we will briefly define protean and boundaryless career attitudes. Although sometimes used interchangeably the constructs have different meanings (Briscoe and Hall 2006). It is important to state that these constructs describe career attitudes, not vocational behavior (Briscoe and Hall 2006; Briscoe et al. 2006). Protean and boundaryless career attitudes can be considered to be key drivers that can indirectly affect career outcomes via actual behavior. For example, placing a high value on protean career attitude might result in higher goal-setting and a greater investment of effort because one feels responsible for one's career and wants to act according to one's own values and aspirations.

\section{Protean career attitude}

The protean career concept was introduced by Hall $(1976,2002)$ as a reaction to changing career pathways that contained more freedom and growth as well as self- 
determination for individuals. The term protean stems from a metaphor of Proteus, a sea god in Greek mythology who had the gift of prophecy and used metamorphosis to hide his knowledge from others. Protean is a synonym for being flexible, adaptive, and changeable. The protean career is defined "as a career in which the person is 1) values-driven in the sense that the person's internal values provide the guidance and measure of success for individual's career; and 2) self-directed in personal career management - having the ability to be adaptive in terms of performance and learning demands" (Briscoe and Hall 2006, p. 8). People with a protean career attitude are values-driven as they shape their career according to their own internal values and beliefs in contrast to, for example, organizational values and beliefs, and they are self-directed as they pursue their careers based on personally defined career goals. People with a protean career attitude use their personal identity as a guide for career decisions.

\section{Boundaryless career attitude}

A person with a boundaryless mindset, "navigates the changing work landscape by enacting a career characterized by different levels of physical and psychological movement" (Sullivan and Arthur 2006, p.9). DeFillippi and Arthur (1994) developed the boundaryless career concept as a response to changes in the direction of more permeable (organizational) boundaries. The boundaryless career attitude refers to organizational mobility preference (i.e., people's physical mobility) and a boundaryless mindset (i.e., people's psychological mobility). Organizational mobility preference means an attitude to conduct actual moves between different occupations, jobs, and organizations. People with a high organizational mobility preference choose to work in several different organizations and actually cross organizational boundaries by taking employment in another company. In contrast, a boundaryless mindset refers to an individual's mental ability to be mobile. A person with a boundaryless mindset enjoys working on projects with people across many organizations and feels energized and enthusiastic about engaging in new experiences and situations outside of the organization.

\section{Present research}

In the present study we try to theoretically integrate two lines of research and to empirically test whether protean and boundaryless career attitudes are associated with subjective and objective career success. Following the definition of protean and boundaryless career attitudes, subjective career success is often considered as one major indicator of success; consequently, studies in this field focus on subjective career success (De Vos and Soens 2008; Hall 2002). However, research on mobility as well as on predictors of career success suggests that it may be promising to predict objective career success by protean and boundaryless career attitudes (Abele and Spurk 2009b; Feldman and Ng 2007).

\section{Development of hypotheses}

\subsection{Career attitudes and subjective career success}

When referring to the "career learning cycle", Hall (2002) postulates that individuals with protean career attitudes strive for psychological success. To achieve success they set themselves challenging goals and invest a lot of effort which results in success or failure and subsequently a certain level of psychological success. People with a protean career attitude self-inquire to a higher extent, implying that they contemplate why they engage in certain behaviors. Reflection about one's behavior as well as continuously learning and evaluating oneself should result in a better adjustment to new work environments (Hall 2002) and a positive evaluation of one's career.

There is some empirical evidence for a positive association between protean career attitudes and subjective career success. In a study with 621 German executives and professionals, Gasteiger (2007) found that a protean career attitude (i.e., self-directed career management) was positively associated with career satisfaction and the subjective appraisal of being more successful in comparison to one's colleagues. De Vos and Soens (2008) investigated the relationship between protean career attitude (self-directed career management) and career success outcomes (career satisfaction and perceived employability) in a sample of 289 Belgian employees. They found that a protean career attitude is a significant predictor of subjective career success. Although there are only a few studies, the results show that a protean career attitude is a significant predictor of subjective career success and perceived employability. Regarding the other component of the protean career attitude, i.e., the values-driven career attitude, even fewer empirical findings have been reported. Only in the Gasteiger (2007) study reported correlations between the values-driven career attitude and several forms of career success. Gasteiger (2007) found no correlations between a values-driven career attitude and subjective or objective career success. Interestingly, other research has found correlations between protean career attitudes and other career-relevant variables. For instance, Briscoe et al. (2006) found positive associations between both components of the protean career attitude scale and proactive personality. Bateman and Crant (1993) and Button et al. (1996) found 
positive relationships with a learning goal orientation. Earlier research has shown positive relationships between these related constructs and subjective and objective career success (Abele and Spurk 2009b; Fuller and Marler 2009; Seibert et al. 1999). Thus, findings on the relationship between a protean career attitude and subjective career success are scarce and inconclusive but the majority of studies suggest a positive relationship.

Hypothesis 1: A values-driven career attitude is positively associated with subjective career success.

Hypothesis 2: Self-directed career management is positively associated with subjective career success.

In sum, building on conceptual considerations and previous findings, we anticipate that the two dimensions of a protean career attitude (i.e., values-driven career attitude and self-directed career management) are positively related to subjective career success.

\subsection{Career attitudes and objective career success}

Employees in contemporary work environments are increasingly required to self-manage and self-direct their careers. People with a protean career attitude show career self-management behaviors (De Vos and Soens 2008) which should translate into objective career success as they meet current job requirements and because these persons act more adaptable and optimistic in unforeseen career situations, such as downsizing or labor market changes (Hall 2002). Moreover, there are positive correlations between salary and self-efficacy (Abele and Spurk 2009b) as well as proactive personality (Seibert et al. 1999, 2001) which are both also positively related to protean career attitudes (Briscoe et al. 2006).

Our hypotheses concerning organizational mobility preference and objective success are derived from research on career mobility. Feldman and $\mathrm{Ng}$ (2007) argue that interorganizational mobility in terms of actual transitions tends to be positively related with objective career success, yet not necessarily with subjective career success. Basically, they suggest a positive correlation between interorganizational mobility and objective career success for two reasons.
First, they argue that people often change their jobs only when a significant pay raise or promotion occurs. People are more motivated to make an organizational move when they expect positive rewards. Second, when people change their jobs they acquire new skills and gather new experiences, which in turn increase their human capital (Becker 1964), which leads to more objective career success. Showing career mobility enhances individuals' job-related skills and knowledge and broadens individuals' experience in dealing with different clients from different industries. Moreover, social capital theory (Burt 1992; Granovetter 1973) predicts that job mobility is positively associated with salary. Social capital includes an individual's actual and potential resources from social networks. From an individual-level perspective, a person with high job mobility will have more opportunities for building and maintaining external contacts associated with objective career success (Wolff and Moser 2009).

Building on the above considerations, we anticipate positive correlations between self-directed career management as a facet of the protean career attitude as well as organizational mobility preference as a facet of the boundaryless career attitude and objective career success.

Hypothesis 3: Self-directed career management is positively associated with objective career success.

Hypothesis 4: Organizational mobility preference is positively associated with objective career success.

We do not state an explicit hypothesis on the relationship between boundaryless mindset and career success. From a theoretical viewpoint, it is on the one hand conceivable that the relationship between a boundaryless mindset and career success is positive (e.g., via networking) but on the other hand a negative relationship might also be possible (e.g., due to dissatisfaction by upward comparisons with colleagues from other companies). Nevertheless, as we are interested in testing the complete conceptualization of protean and boundaryless career attitudes, we will analyze the relationship between boundaryless mindset and career success in an explorative fashion. Our conceptual model is depicted in Fig. 1. Summarizing, we hypothesize that the two dimensions of a protean career attitude (i.e., values-

Fig. 1 Conceptual model

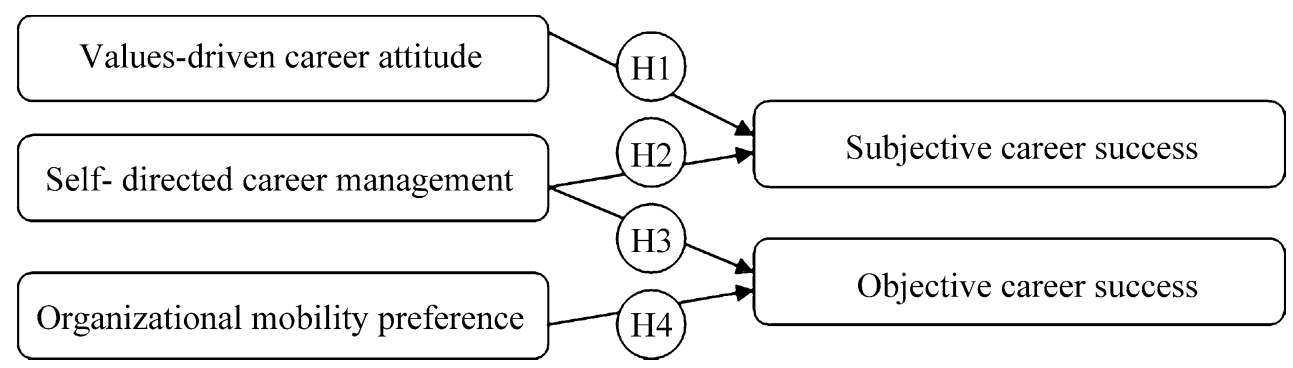


driven career attitude and self-directed career management) are positively related to subjective success and that self-directedness as a facet of the protean career attitude as well as organizational mobility preference as a facet of the boundaryless career attitude are positively related to objective career success.

\section{Method}

\subsection{Procedure}

In 2008, we carried out an online survey with two internationally operating engineering and manufacturing companies. We chose these companies because they provide flexible structures and modern personnel systems offering a lot of opportunities for intra- and inter-organizational job changes. From 220 participants whom we contacted via e-mail, a total of 127 responded to our online survey (response rate: $57.7 \%$ ). From these 127 participants, we had to exclude 11 participants because they quit the survey at the very beginning (response rate for the final 116 participants: $52.7 \%$ ). Participation was voluntary, we assured confidentiality and explained that the study was conducted in agreement with - but independent of - the company's management. Participants filled out questionnaires during working time.

\subsection{Participants}

The sample consisted of 116 German employees (37.1\% female). On average, participants were 32.86 years old with a range from 18 to 55 years $(S D=7.08)$. The sample was highly educated and all participants held a university or comparable degree. The average amount of working hours per week was $42.62 \mathrm{~h}(S D=3.72)$ and participants possessed professional experience of 6.39 years $(S D=6.34)$ on average.

\subsection{Measures}

Protean and boundaryless career attitudes. Protean and boundaryless career attitudes are measured with a new scale developed by Briscoe et al. (2006). Although sometimes operationalized in other ways (e.g., single item indicators) this scale is the only measure that captures all facets of protean and boundaryless career attitudes.

Protean career attitudes. The protean career attitudes were measured with the Values-Driven Scale and the Self-Directed Career Management Scale from the Protean Career Attitude scale (Briscoe et al. 2006). Specifically, to assess the values-driven career attitude, participants indicated on six items the extent to which they pursue their career with regard to their own values versus, for example, organizational values (e.g., "What's most important to me is how I feel about my career success, not how other people feel about it"). Cronbach's $\alpha$ was 0.64. To assess the self-directed career attitude, participants indicated on eight items using 5-point Likert scales $(1=$ totally disagree to $5=$ totally agree) the extent to which they considered themselves to be mainly responsible for their careers (e.g., "I am responsible for my success or failure in my career"). Cronbach's $\alpha$ was 0.83 .

Boundaryless career attitudes. Boundaryless career attitudes were measured with the Organizational Mobility Preference and Boundaryless Mindset Scale from the Boundaryless Career Attitude Scale (Briscoe et al. 2006). The Organizational Mobility Preference scale measures the preference to remain with a single (or multiple) employer(s) by the use of five items. A sample item (reverse coded) is "If my organization provided lifetime employment, I would never desire to seek work in other organizations". Cronbach's $\alpha$ was 0.78 . The Boundaryless Mindset scale assesses with eight items the extent to which a person is comfortable with initiating and pursuing work-related relationships across organizational boundaries (e.g., "I would enjoy working on projects with people across many organizations"). Cronbach's $\alpha$ was 0.79 . The reliabilities of the scales are comparable to reliabilities that have been reported in earlier studies by Briscoe et al. (2006).

Subjective career success. We operationalized subjective career success in terms of career satisfaction and in terms of a comparison with colleagues. Career satisfaction $(\alpha=0.84)$ was measured with a German translation of the career satisfaction scale (Greenhaus et al. 1990). The scale comprises five items (sample item: "I am satisfied with the progress I have made towards meeting my overall career goals"). Participants responded on 5-point scales $(1=$ not at all to $5=$ very much $)$. The comparison with colleagues was measured by one single item (cf. Abele and Spurk 2009a: "Compared with your colleagues, how successful do you think your career development has been so far?"). Participants based their responses on a 5-point rating scale $(1=$ less successful to $5=$ more success$f u l)$.

Objective career success. We measured objective career success as annual salary and number of promotions. The salary variable could vary between zero and 11 . More specifically, we assessed annual salary before taxes in twelve equal steps from "no salary", coded as 0; "less than $€ 10,000$ ", coded as 1 to "less than $€ 100,000$ ", coded as 10; and "more than $€ 100,000$ "; coded as 11 . For promotions, we asked participants to indicate the number of promotions they had experienced during their career (cf. Abele and Spurk 2009b; Boudreau et al. 2001). 
Table 1 Means, standard deviations, and zero-order correlations between study variables

\begin{tabular}{|c|c|c|c|c|c|c|c|c|c|c|c|c|c|}
\hline & & $M$ & $S D$ & 1 & 2 & 3 & 4 & 5 & 6 & 7 & 8 & 9 & 10 \\
\hline 1 & Age & 32.86 & 7.08 & $(-)$ & & & & & & & & & \\
\hline 2 & Gender $^{\mathrm{a}}$ & - & - & -0.09 & $(-)$ & & & & & & & & \\
\hline 3 & Working hours & 42.62 & 3.72 & 0.01 & -0.18 & $(-)$ & & & & & & & \\
\hline 4 & Values-driven career attitude & 3.30 & 0.53 & -0.04 & -0.11 & 0.01 & $(0.64)$ & & & & & & \\
\hline 5 & Self-directed career management & 3.92 & 0.55 & 0.08 & -0.01 & 0.11 & $0.40^{* *}$ & $(0.83)$ & & & & & \\
\hline 6 & Organizational mobility preference & 3.31 & 0.74 & -0.10 & 0.00 & $0.23^{*}$ & 0.12 & $0.31^{* *}$ & $(0.78)$ & & & & \\
\hline 7 & Boundaryless mindset & 3.94 & 0.51 & -0.09 & -0.04 & $0.39^{* *}$ & 0.07 & $0.31^{* *}$ & $0.25^{* *}$ & $(0.79)$ & & & \\
\hline 8 & Career satisfaction & 3.85 & 0.64 & 0.03 & $-0.27^{*}$ & $0.23^{*}$ & 0.11 & $0.23^{*}$ & -0.01 & 0.04 & $(0.84)$ & & \\
\hline 9 & Comparison with colleagues & 3.52 & 0.49 & 0.03 & $-0.26^{* *}$ & $0.35^{* *}$ & 0.02 & $0.30^{* *}$ & 0.11 & $0.20^{*}$ & $0.47^{* *}$ & $(-)$ & \\
\hline & Promotions ${ }^{b}$ & 2.55 & 1.29 & 0.18 & $-0.32^{* *}$ & $0.42^{* *}$ & 0.00 & 0.08 & -0.03 & $0.28^{*}$ & $0.37^{* *}$ & $0.38^{* *}$ & $(-)$ \\
\hline & Salary ${ }^{\mathrm{c}}$ & 5.42 & 2.24 & $0.58^{* *}$ & $-0.29^{* *}$ & $0.44^{* *}$ & -0.03 & $0.21^{*}$ & $0.21^{*}$ & 0.20 & $0.21^{*}$ & $0.37^{* *}$ & $0.38^{* *}$ \\
\hline
\end{tabular}

Note: $N=116 .{ }^{*} p<0.05 .{ }^{* *} p<0.01 .{ }^{* * *} p<0.001 .{ }^{\mathrm{a}}$ Gender is coded as $0=$ male, $1=$ female. ${ }^{\mathrm{b}}$ Promotions are the number of advancements. "Salary was measured in twelve equal steps and could vary between zero "no salary" to 11 "more than $€ 100.000$ ".

Control variables. As earlier studies found that some variables strongly influence career success, we statistically controlled for gender (Kirchmeyer 1998; Fuller 2008), work hours (Spurk and Abele, in press), and age ( $\mathrm{Ng}$ et al. 2005).

\section{Results}

\subsection{Descriptive findings}

Table 1 displays means, standard deviations, and zero-order correlations between study variables.

Correlations between the four subscales of the Protean and Boundaryless Career Attitude scale were small to medium between the four subscales $(r=0.07, n s$ to $r=0.40, p<0.01)$. We found the lowest correlation between the values-driven career attitude and a boundaryless mindset $(r=0.07, n s)$ and the highest correlation between the values-driven career attitude and self-directed career management $(r=0.40, p<0.01)$. Our findings are in accordance with Briscoe and Hall's (2006) conceptual considerations that the subscales are overlapping, but nevertheless distinct, concepts. For example, a person might be very self-directed and proactively craft his/her career by organizational mobility. Another very self-directed person might choose career opportunities within one single organization but seek constant contacts with organizations from outside. Moreover, the correlations between subscales are comparable to previous findings on the correlations between subscales (Briscoe and Hall 2006).

Regarding the career attitudes and the success measures, we found positive correlations between self-directed career management and salary $(r=0.21, p<0.05)$, career satisfac- tion $(r=0.23, p<0.05)$, and a comparison with colleagues ( $r=0.30, p<0.01)$. Also, there were positive correlations between a boundaryless mindset and promotions $(r=0.28$, $p<0.05)$ as well as a comparison with colleagues $(r=0.20$, $p<0.05)$. Finally, there was a positive correlation between organizational mobility preference and salary $(r=0.21$, $p<0.05)$ and no correlation between the values-driven career attitude and any success measure.

\subsection{Preliminary analyses - confirmatory factor analyses}

Following Briscoe et al. (2006), we assumed that a four factor model should be the best solution and conducted confirmatory factor analyses (CFAs). CFA is a special case of structural equation modelling (SEM), also known as the covariance structure (McDonald 1978) or the linear structural relationship (LISREL) model (Jöreskog and Sörbom 2004). In our case, items were specified to load only on the factor they were developed to measure (values-directed, self-directed, organizational mobility preference, boundaryless mindset). Moreover, we assumed that these four factors are correlated. This four factor model with correlated factors is in line with assumptions from earlier research, assuming that the four components of protean and boundaryless career attitudes are independent yet correlated constructs (cf. Briscoe et al. 2006; Briscoe and Hall 2006). Specifically, we tested a four factor model against a one-factor model and a two-factor model (i.e., protean and boundaryless career attitude). The four-factor model fits the data better than the one-factor $\left(\Delta \chi^{2}(6)=464.34, p<0.01\right)$ and the twofactor $\left(\Delta \chi^{2}(5)=168.84, p<0.001\right)$ solution (fit indices: one-factor model: $\chi^{2}=877.77, \mathrm{df}=308, \mathrm{CFI}=0.31$, $\mathrm{TLI}=0.26, \quad \mathrm{RMSEA}=0.13, \quad \mathrm{SRMR}=0.15 ;$ two-factor 
Table 2 Predicting subjective career success from protean and boundaryless career attitudes
Table 3 Predicting objective career success from protean and boundaryless career attitudes

\begin{tabular}{lllll}
\hline & \multicolumn{2}{c}{ Career satisfaction } & \multicolumn{2}{c}{ Comparison with colleagues } \\
& $\Delta R^{2}$ & $\beta$ & $\Delta R^{2}$ & $\beta$ \\
\hline Step 1: control variables & $0.11^{* * *}$ & - & $0.16^{* * *}$ & - \\
Gender $^{\text {a }}$ & - & $-0.23^{*}$ & - & $-0.23^{* *}$ \\
Age & - & -0.03 & - & -0.03 \\
Working hours & - & $0.25^{*}$ & - & $0.28^{* * *}$ \\
Step 2: protean and boundaryless career & $0.08^{* *}$ & - & $0.09^{* * *}$ & - \\
attitudes & & & & -0.15 \\
Values-driven career attitude & - & 0.02 & - & $0.34^{* * *}$ \\
Self-directed career management & - & $0.28^{* *}$ & - & -0.01 \\
Organizational mobility preference & - & -0.14 & - & -0.05 \\
Boundaryless mindset & - & -0.12 & - & \\
\hline
\end{tabular}

Note: $N=116 .{ }^{*} p<0.05 .{ }^{* *} p<0.01 .{ }^{* * *} p<0.001 .{ }^{\text {a }}$ Gender is coded as $0=$ male, $1=$ female.

\begin{tabular}{lllll}
\hline & Promotions $^{\mathrm{b}}$ & \multicolumn{2}{l}{ Salary } \\
& $\Delta R^{2}$ & $\beta$ & $\Delta R^{\mathrm{c}}$ & $\beta$ \\
\hline Step 1: control variables & $0.27^{* * *}$ & - & $0.57^{* * *}$ & - \\
Gender $^{\mathrm{a}}$ & - & $-0.28^{*}$ & - & $-0.19^{*}$ \\
Age & - & 0.11 & - & $0.56^{* * *}$ \\
Working hours & - & $0.33^{* *}$ & - & $0.34^{* * *}$ \\
Step 2: protean and boundaryless career & 0.01 & - & $0.02^{*}$ & - \\
attitudes & & & & -0.06 \\
Values-driven career attitude & - & -0.04 & - & 0.09 \\
Self-directed career management & - & 0.03 & - & $0.15^{*}$ \\
Organizational mobility preference & - & -0.10 & - & 0.04 \\
Boundaryless mindset & - & 0.12 & - & - \\
\hline
\end{tabular}

Note: $N=116 .{ }^{*} p<0.05 .{ }^{* *} p<0.01 .{ }^{* * *} p<0.001 .{ }^{\mathrm{a}}$ Gender is coded as $0=$ male, $1=$ female.${ }^{\mathrm{b}}$ Promotions are the number of promotions. ${ }^{\mathrm{c}}$ Salary was measured in twelve equal steps and could vary between zero "no salary" to 11 "more than $€ 100.000$ ". model: $\chi^{2}=582,27, \mathrm{df}=307, \mathrm{CFI}=0.53, \mathrm{TLI}=0.49$, RMSEA $=0.11, \quad$ SRMR $=0.14$ ). Consequently, as also shown by Briscoe et al. (2006), the four-factor solution was the best one. Thus, we report findings on the four subscales of the protean and boundaryless career attitude scales (best fitting model: $\chi^{2}=413.43, \mathrm{df}=302, \mathrm{CFI}=0.91$, $\mathrm{TLI}=0.90, \quad \mathrm{RMSEA}=0.05, \mathrm{SRMR}=0.08$ ). All items loaded on the expected scales.

\subsection{Test of hypotheses}

Multiple hierarchical regression analyses were used to test our hypotheses. The control variables age, gender, and working hours were entered in the first step, followed by protean (i.e., values-driven career attitude and self-directed career management) and boundaryless (i.e., organizational mobility preference and boundaryless mindset) career attitudes in the second step.
Results for the hypotheses can be seen in Table 2 (subjective career success, i.e., career satisfaction and a comparison with colleagues) and Table 3 (objective career success, i.e., promotions and salary). We will first present findings on subjective career success followed by findings on objective career success.

We postulated that protean, i.e., values-driven $(\mathrm{H} 1)$ and self-directed (H2), career attitudes are positively associated with subjective career success. Our findings show in support of Hypothesis 2 that self-directed career management is positively related with career satisfaction $(\beta=0.28$, $p<0.01)$ and a comparison with colleagues $(\beta=0.34$, $p<0.01)$. However, we did not find support for Hypothesis 1 because a values-driven attitude was neither related to career satisfaction $(\beta=0.02, n s)$ nor to a comparison with colleagues $(\beta=-0.15, n s)$.

Regarding the controls, gender and working hours had effects on career satisfaction and a comparison with colleagues $(\beta=-0.23, p<0.05, \beta=0.25, p<0.01$ and 
$\beta=-0.23, p<0.01, \beta=0.28, p<0.01$, respectively). Men felt more successful than women and persons working more felt more successful than persons working less. In case of career satisfaction, $11 \%$ of variance was explained by the controls and $8 \%$ of variance was explained over and above the controls by the career attitudes. In case of a comparison with colleagues, $16 \%$ of variance was explained by the controls and $9 \%$ of variance was explained over and above the controls by the career attitudes.

Regarding objective career success indicators, we assumed that the subscale self-directed career management (H3) from the protean career attitude and the subscale organizational mobility preference (H4) from the boundaryless career attitude are positively associated with promotions and salary. Contrary to our assumptions, there were no significant associations between self-directed career management $(\beta=-0.04, n s)$ or organizational mobility preference $(\beta=-0.10, n s)$ and promotions, nor of self-directed career management $(\beta=0.09, n s)$ and salary. However, in accordance with our assumptions and partially confirming Hypothesis 4, we found a positive association between organizational mobility preference $(\beta=0.15$, $p<0.01$ ) and salary.

Regarding the controls, gender $(\beta=-0.28, p<0.05)$ and working hours $(\beta=0.33, p<0.01)$ had an effect on promotions. $27 \%$ of variance was explained by the controls and no significant portion of variance was explained over and above the controls by the career attitudes. In case of salary, gender $(\beta=-0.19, p<0.01)$, age $(\beta=0.56, p<0.001)$, and working hours $(\beta=0.36, p<0.001)$ explained $57 \%$ of variance and $2 \%$ of variance was explained over and above the controls by the career attitudes.

\section{Discussion}

The goal of the present study was, first, to empirically investigate simultaneously the relationship between protean and boundaryless career attitudes and both subjective and objective career success. Second, we wanted to integrate assumptions and findings from research on protean and boundaryless career attitudes with research on career mobility to better understand the role of career attitudes in today's frequently changing and complex work environment.

Our findings reveal that those individuals with a protean career attitude (namely those high in self-directed career management) and those individuals with a boundaryless career attitude (namely those high in organizational mobility preference) report higher levels of subjective (career satisfaction and comparison with colleagues) and objective (salary) career success, respectively. Our finding of the positive relationship between the subscale self-directed career management from the protean career attitude scale and subjective career success is in accordance with the emphasis of the subjective perspective among protean career researchers. Individuals who proactively manage their careers are more satisfied with their careers compared to individuals with a more passive career attitude. Also, they judge themselves higher in an explicit comparison with their colleagues. The finding that organizational mobility preference as a subscale of boundaryless career attitude is positively associated with salary is new and extends earlier research by providing empirical support for a positive association between boundaryless career attitudes and objective career success. In this way, our findings combine considerations from research on mobility and predictors of career success with research on protean and boundaryless career attitudes.

Contrary to our expectations, but replicating Gasteiger's (2007) findings, a values-driven career attitude was not related to subjective career success. This may be due to the fact that persons with high values on this subscale are trying to guide their careers according to their own standards, but if these values do not fit with organizational requirements, a high values-driven career attitude might not be associated with subjective career success. In our study we did not find any positive associations between self-directed career management and promotions or salary. It is conceivable that self-directedness is rewarded only in companies that value autonomy and proactive behavior. Future research has to examine such boundary conditions in more detail. Moreover, we could not support our assumption of a positive association between organizational mobility preference and promotions. The willingness to change a company might not always be the best way to get promoted. Sometimes, it might even be wiser to follow a predetermined organizational career track within the same organization, because changing a company also includes uncertainties about career tracks.

\subsection{Limitations}

There are some limitations. The most central one is that our study was cross-sectional. Therefore, we cannot unequivocally determine the direction of influence between study variables. Although theoretical considerations support the view that career attitudes determine career success (e.g., Briscoe et al. 2006; Hall 2002, 2004), we cannot draw firm causal conclusions from our study. Longitudinal studies are needed to clarify the issue of causality between career attitudes and career success. Furthermore, our sample came from one single industry type only. Although we do not assume that our findings are restricted to employees in the technical sector, rewards for acquiring protean and boundaryless career attitudes might, for example, vary depending on whether a person works in the private or 
public sector. Moreover, one may question the validity of our self-reported measure of income. Yet, previous research has shown that archival salary and self-reported salary are closely related (Judge et al. 1995).

\subsection{Implications for practice and research}

Our findings suggest that employees should be encouraged to take responsibility for their careers (Wiese et al. 2002). Verbruggen and Sels (2008) found that self-directed career management can be improved in a sustainable way through career counseling. Self-management strategies are important to help people translate their protean career attitudes into career success (De Vos and Soens 2008).

Future research should investigate the incremental predictive validity of the protean and boundaryless career attitudes beyond existing psychological predictors of career success (e.g., personality, self-efficacy, intelligence) in order to estimate the practical usefulness of career attitudes for career counseling. Furthermore, discriminant validity between protean and boundaryless career constructs and other wellestablished constructs, such as self-management strategies (e.g., selection of goals, optimization as implementation of goal-pursuing behavior), should be investigated in future research. For example, Abele and Wiese (2008) have shown that domain-specific career planning, especially, was important for both subjective career success (career satisfaction, comparative judgment) and objective career success (pay, position). Likewise, future research should investigate in more detail relationships between the protean and boundaryless career attitudes and other non-standard work arrangements, such as temporary agency workers (Galais and Moser 2009), and other career-relevant constructs such as employability (Forrier and Sels 2003), networking (Wolff and Moser 2009), or personal initiative (Frese et al. 1997).

In our introduction, we pointed out that we are concerned here with protean and boundaryless career attitudes, not vocational behavior. In other words, we measured attitudes and assumed positive relationships between attitudes and behavior. However, future research has to determine whether career attitudes actually result in desirable behavior (e.g., effort investment, persistence, career self-management behaviors) and investigate causal relationships between career attitudes and career success, for example, by the use of longitudinal and cross-lagged designs. It is also important to acknowledge that the concepts of protean and boundaryless career attitudes might be applicable only to a minority of the workforce, as the assumed freedom from boundaries and centrality of individual volition might not always be given (Pringle and Mallon 2003; Sullivan and Baruch 2009). Finally, one should be careful in having a too "rosy" view on these newly developed career orientations as sometimes they might not be an expression of agency and self- determination, but only a forced reaction to highly unstable work environments.

\subsection{Conclusion}

Protean career attitudes (namely self-directed career management) have been found to be related to different forms of subjective career success (career satisfaction, self-evaluation of success in comparison with colleagues). Boundaryless career attitudes (namely organizational mobility preference) have been found to be related to one specific indicator of objective success (salary). Summarizing, our findings expand earlier research by showing positive relationships between career attitudes and both subjective and objective career success.

\section{Executive summary}

In times of frequently changing work environments with decreased job stability, it is often no longer possible for an employee to pursue a career within one single organization during his or her lifetime with prescheduled linear upward moves over time. More and more frequently, employees have to take responsibility for their own careers. The protean (Hall 1976, 2004) and boundaryless (Arthur 1994; Arthur and Rousseau 1996) career attitudes have gained special attention during the past few years. A protean career attitude has been characterized as involving a broader perspective, a developmental progression, and viewing a career as a calling and a way to self-fulfillment (Hall 2002). A boundaryless career attitude is characterized by high mobility and a preference for navigating physically and/or psychologically across many organizations (Sullivan and Arthur 2006). Both, protean and boundaryless career attitudes have two components. The protean career attitude consists of a values-driven attitude and self-directed career management; the boundaryless career attitude is composed of an organizational mobility preference and a boundaryless mindset. Previous studies on protean and boundaryless career attitudes have predominantly focused on theoretical and methodological aspects (e.g. Briscoe and Hall 2006) or have investigated only some components of the career attitude constructs (e.g., De Vos and Soens 2008; Gasteiger 2007). Moreover, there have so far been no comprehensive analyses of the relationships of these career attitudes with different facets of career success.

The aim of the current study is twofold: First, we aim to empirically investigate the relationship between protean and boundaryless career attitudes and both subjective (i.e., career satisfaction and success in comparison with colleagues) and objective (i.e., promotions and salary) career success. Thereby we strive towards a more comprehensive 
understanding of similarities and differences of protean and boundaryless career orientations regarding the relationship with career success. Secondly, we want to theoretically integrate assumptions and findings from research on protean and boundaryless career attitudes (Briscoe et al. 2006) with research on predictors of career success (e.g., $\mathrm{Ng}$ et al. 2005).

In the present study we assume a positive relationship between a values-driven attitude and subjective career success (H1) and between self-directed career management and subjective career success (H2). Moreover, we assume a positive relationship between self-directed career management and objective career success (H3) and organizational mobility preference and objective career success (H4).

We conducted an online survey with 116 employees from two internationally operating engineering and manufacturing companies. Results from multiple hierarchical regression analyses revealed that after controlling for some relevant variables (work hours, age, gender) self-directed career management was positively related with career satisfaction as well as with success in comparison with colleagues. In other words, employees who self-direct their careers are more satisfied and evaluate their success as being higher in comparison with others. Moreover, we found a positive relationship between organizational mobility preference and salary. This implies that people who have a preference for changing between organizations earn more than people who do not have a preference for change. In summary, our results show that components of the protean career attitude are rather more related with subjective career success and that components of the boundaryless career attitude are more related with objective career success. Our findings suggest that a differential analysis of both career attitudes is valuable with respect to the prediction of career success.

\section{Kurzfassung}

In sich immer schneller verändernden Arbeitswelten mit abnehmender Arbeitsplatzsicherheit ist es häufig nicht mehr möglich, das Berufsleben in einem Unternehmen mit vorgezeichneten Aufstiegsmöglichkeiten zu verbringen. Immer häufiger müssen Beschäftigte selbst Verantwortung für ihre Laufbahn übernehmen. Die proteische (engl. protean) (Hall 1976, 2004) und entgrenzte (engl. boundaryless) (Arthur 1994; Arthur u. Rousseau 1996) Laufbahneinstellung haben dabei seit einigen Jahren besondere Beachtung gefunden. Eine proteische Laufbahneinstellung ist gekennzeichnet durch die Einnahme einer umfassenderen Perspektive, dem Bedürfnis einer immer fortschreitenden persönlichen Entwicklung und der Sichtweise, die eigene Laufbahn als Berufung und Weg zur Selbstverwirklichung (Hall 2002) $\mathrm{zu}$ verstehen. Eine entgrenzte Laufbahneinstellung ist gekennzeichnet durch eine hohe Mobilität und Präferenz für physische und/oder psychische Mobilität zwischen vielen Organisationen (Sullivan u. Arthur 2006). Beide Laufbahneinstellungen setzen sich aus zwei Komponenten zusammen. Die proteische Laufbahneinstellung besteht aus einer wertegeleiteten Einstellung (engl. values-driven attitude) und dem selbstgesteuerten Laufbahnmanagement (engl. self-directed career management). Die entgrenzte Laufbahneinstellung besteht aus einer organisationalen Wechselbereitschaft (engl. organizational mobility preference) und einer entgrenzten Denkweise (engl. boundaryless mindset). Vorherige Studien zu proteischen und entgrenzten Laufbahneinstellungen haben sich auf theoretische und methodische Aspekte (z. B. Briscoe u. Hall 2006) oder nur auf die Analyse einzelner Komponenten dieser Laufbahneinstellungen konzentriert (z. B. De Vos u. Soens 2008; Gasteiger 2007). Zudem wurde bisher nicht umfassend untersucht, welchen Zusammenhang diese Laufbahneinstellungen mit verschiedenen Facetten des Berufserfolgs aufweisen.

Dieser Beitrag verfolgt zwei Zielsetzungen: Erstens untersuchen wir den Zusammenhang aller Komponenten von proteischen und entgrenzten Laufbahneinstellungen und subjektivem (d. h. Karrierezufriedenheit und Erfolg im Vergleich mit Kollegen) sowie objektivem (d. h. Beförderung und Gehalt) Berufserfolg. Damit möchten wir einen umfassenderen Einblick in Gemeinsamkeiten und Unterschiede von proteischen und entgrenzten Laufbahneinstellungen hinsichtlich des Zusammenhangs mit Berufserfolg bekommen. Zweitens möchten wir Forschung zu proteischen und entgrenzten Laufbahneinstellungen (Briscoe et al. 2006) mit Forschung zu Prädiktoren von Berufserfolg (z. B. Ng et al. 2005) verknüpfen.

Wir nehmen in unserer Untersuchung einen positiven Zusammenhang zwischen wertgeleiteter Einstellung und subjektivem Berufserfolg (H1) sowie zwischen selbstgesteuertem Laufbahnmanagement und subjektivem Berufserfolg (H2) an. Des Weiteren nehmen wir einen positiven Zusammenhang zwischen selbstgesteuertem Laufbahnmanagement und objektivem Berufserolg (H3) sowie organisationaler Wechselbereitschaft $(\mathrm{H} 4)$ und objektivem Berufserfolg an.

An unserer Onlinefragebogenuntersuchung nahmen 116 Beschäftigte aus zwei international operierenden Elektronik- und Handelsunternehmen teil. Unsere Ergebnisse aus multiplen hierarchischen Regressionsanalysen zeigten, dass nach Kontrolle weiterer relevanter Variablen (Arbeitszeit, Alter, Geschlecht) das selbstgesteuerte Laufbahnmanagement positiv mit Karrierezufriedenheit und dem Erfolg im Vergleich zu Kollegen zusammenhing. Anders ausgedrückt, Personen, welche ihre Laufbahn eigenverantwortlich steuern, sind mit den bisherigen Resultaten 
in ihrer Laufbahn zufriedener und schätzen ihren Erfolg höher ein. Außerdem fanden wir einen positiven Zusammenhang zwischen organisationaler Wechselbereitschaft und dem Gehalt. Das heißt, Personen, welche den Wechsel zwischen Organisationen prinzipiell als erstrebenswert ansehen bzw. diesem nicht abgeneigt sind, verdienen mehr als Personen, die dies nicht tun. Zusammenfassend zeigen unsere Ergebnisse, dass Komponenten der proteischen Laufbahneinstellung eher mit subjektivem Berufserfolg und Komponenten der entgrenzten Laufbahneinstellungen eher mit objektivem Berufserfolg zusammenhängen. Insgesamt zeigt sich somit, dass eine differenzierte Betrachtung beider Laufbahneinstellungen durchaus prognostischen Wert bezüglich der Erreichung von Berufserfolg besitzt.

Acknowledgements We would like to thank Andrea E. Abele and Daniela Bernhardt for insightful comments on an earlier version of this paper and Marie Dikmani, Tobias Eisenmann, Anja Langer, Joel Nißlein, and Teresa Schulze for their help in data collection. Parts of this study were presented at the 1st International Workshop on Career Success: Approaches from Economics and Psychology at the Institute for Employment Research, December 2009, Nuremberg, Germany.

\section{References}

Abele, A.E., Spurk, D.: How do objective and subjective career success interrelate over time? J. Occup. Organ. Psych. 82, 803-824 (2009a)

Abele, A.E., Spurk, D.: The longitudinal impact of self-efficacy and career goals on objective and subjective career success. J. Vocat. Behav. 74, 53-62 (2009b)

Abele, A.E., Spurk, D., Volmer, J.: The construct of career success: measurement issues and an empirical example. ZAF DOI 10.1007/s12651-010-0034-6 (2010, this issue).

Abele, A.E., Wiese, B.S.: The nomological network of self-management strategies and career success. J. Occup. Organ. Psych. 81, 733-749 (2008)

Arthur, M.B.: The boundaryless career: a new perspective for organizational inquiry. J. Organ. Behav. 15(Special issue), 295-306 (1994)

Arthur, M.B., Rousseau, D.M.: The Boundaryless Career: a New Employment Principle for a New Organizational Era. Oxford University Press, New York (1996)

Bateman, T.S., Crant, J.M.: The proactive component of organizational behaviour. J. Organ. Behav. 14, 103-118 (1993)

Becker, G.S.: Human Capital: a Theoretical and Empirical Analysis, with Special Reference to Education, 3rd edn. University of Chicago Press, Chicago (1993)

Boudreau, J.W., Boswell, W.R., Judge, T.A.: Effects of personality on executive career success in the United States and Europe. J. Vocat. Behav. 58, 53-81 (2001)

Briscoe, J.P., Hall, D.T.: The interplay of boundaryless and protean careers: combinations and implications. J. Vocat. Behav. 69, 4-18 (2006)

Briscoe, J.P., Hall, D.T., Frautschy DeMuth, R.L.F.: Protean and boundaryless careers: an empirical exploration. J. Vocat. Behav. 69, 30-47 (2006)

Burt, R.: Structural Holes: the Social Structure of Competition. Harvard University Press, Cambridge, MA (1992)

Button, S.B., Mathieu, J.E., Zajac, D.M.: Goal orientation in organizational research: a conceptual and empirical foundation. Organ. Behav. Hum. Dec. 67, 26-48 (1996)
DeFillippi, R.J., Arthur, M.B.: The boundaryless career: a competencybased perspective. J. Organ. Behav. 15, 307-324 (1994)

Dette, E.D., Abele, A.E., Renner, O.: Zur Definition und Messung von Berufserfolg - theoretische Überlegungen und metaanalytische Befunde zum Zusammenhang von externen und internen Laufbahnerfolgsmaßen. Z. Personalpsychol. 3, 170-183 (2004)

De Vos, A., Soens, N.: Protean attitude and career success: the mediating role of self-management. J. Vocat. Behav. 73, 449-456 (2008)

Feldman, D.C., Ng, T.W.H.: Mobility, embeddedness, and success. J. Manage. 33, 350-377 (2007)

Forrier, A., Sels, L.: The concept employability: A complex mosaic. Int. J. Hum. Resour. Dev. Man. 3, 102-124 (2003)

Frese, M., Fay, D., Hilburger, T., Leng, K.: The concept of personal initiative: operationalization, reliability and validity of two German samples. J. Occup. Organ. Psych. 70, 139-161 (1997)

Fuller, S.: Job mobility and wage trajectories for men and women in the United States. Am. Sociol. Rev. 73, 158-183 (2008)

Fuller, J.B., Marler, L.E.: Change driven by nature: a meta-analytic review of the proactive personality literature. J. Vocat. Behav. 75, 329-345 (2009)

Gasteiger, R.M.: Selbstverantwortliches Laufbahnmanagement. Das proteische Erfolgskonzept. Hogrefe, Göttingen (2007)

Galais, N., Moser, K.: Organizational commitment and the well-being of temporary agency workers - a longitudinal study. Hum. Relat. 62, 589-620 (2009)

Greenhaus, J.H., Parasuraman, S., Wormley, W.M.: Effects of race on organizational experiences, job performance evaluations, and career outcomes. Acad. Manage. J. 33, 64-86 (1990)

Granovetter, M.: The strength of weak ties. Am. J. Sociol. 78, 13601380 (1973)

Hall, D.T.: Careers in organizations. Scott Foresman, Glenview IL (1976)

Hall, D.T.: Careers in and out of organizations. Sage, Thousand Oaks, CA (2002)

Hall, D.T.: The protean career: a quarter-century journey. J. Vocat. Behav. 65, 1-13 (2004)

Heslin, P.A.: Conceptualizing and evaluating career success. J. Organ. Behav. 26, 113-136 (2005)

Inkson, K.: Protean and boundaryless careers as metaphors. J. Vocat. Behav. 69, 48-63 (2006)

Jöreskog, K.G., Sörbom, D.: LISREL 8.7 for Windows. Scientific Software International Inc., Lincolnwood, IL (2004)

Judge, T.A., Cable, D.M., Boudreau, J.W., Bretz, R.D.: An empirical investigation of the predictors of executive career success. Pers. Psychol. 48, 485-519 (1995)

Kirchmeyer, C.: Determinants of managerial career success: evidence and explanation of male/female differences. J Manage. 24, 673-692 (1998)

McDonald, R.P.: A simple comprehensive model for the analysis of covariance structures. Brit. J. Math. Stat. Psy. 31, 59-72 (1978)

Ng, T.W.H., Eby, L.T., Sorensen, K.L., Feldman, D.C.: Predictors of objective and subjective career success. A meta-analysis. Pers. Psychol. 58, 367-408 (2005)

Pringle, J.K., Mallon M.: Challenges to the boundaryless career odyssey. Int. J. Hum. Res. Manage. 15(4), 839-853 (2003)

Seibert, S.E., Crant, J.M., Kraimer, M.L.: Proactive personality and career success. J. Appl. Psychol. 84, 416-427 (1999)

Seibert, S.E., Kraimer, M.L., Crant, J.M.: What do proactive people do? A longitudinal model linking proactive personality and career success. Pers. Psychol. 54, 845-874 (2001)

Spurk, D., Abele, A.E.: Who earns more and why? A multiple mediation model from personality to salary. J. Bus. Psychol. (in press)

Sullivan, S.E., Arthur, M.B.: The evolution of the boundaryless career concept: examining physical and psychological mobility. J. Vocat. Behav. 69, 19-29 (2006) 
Sullivan, S.N., Baruch, Y.: Advances in career theory and research: critical review and agenda for future exploration. J. Manage. 35(6), 1452-1571 (2009)

Super, D.E.: The psychology of careers: an introduction to vocational development. Harper and Bros, New York (1957)

Verbruggen, M., Sels, L.: Can career self-directed career management be improved through counseling? J. Vocat. Behav. 73, 318-327 (2008)

Wolff, H.-G., Moser, K.: Effects of networking on career success: a longitudinal study. J. Appl. Psychol. 94, 196-206 (2009)

Wiese, B.S., Freund, A.M., Baltes, P.B.: Subjective career success and emotional well-being: longitudinal predictive power of selection, optimization, and compensation. J. Vocat. Behav. 60, 321-335 (2002)
Judith Volmer, associate at the Chair of Social Psychology at the University of Erlangen-Nuremberg. Studied psychology at the University of Bielefeld; Ph.D. at the Universities of Braunschweig and Konstanz; research stays in the US; currently completing her Habilitation at the University of Erlangen-Nuremberg.

Research topics: Performance and career success; affect in organizations; leadership.

e-mail: judith.volmer@sozpsy.phil.uni-erlangen.de

Daniel Spurk, assistant at the Chair of Social Psychology at the University of Erlangen-Nuremberg. Studied psychology at the University of Erlangen-Nuremberg; currently completing his Ph.D. at the University of Erlangen-Nuremberg.

Research topics: Career success; career development; self-efficacy. e-mail: daniel.spurk@sozpsy.phil.uni-erlangen.de 